The Labore Journal of Economics

Special Edition

\title{
Governing the State: Problems Specific to Pakistan
}

\section{Khaled Ahmed"}

In our environment governance usually means law and order but in its broadest sense it means thinking about how to steer the economy and society, and how to reach collective goals'. Multinational institutions hold seminars on governance but carefully avoid discussions impinging on the third world scale's sovereignty; they focus instead on administrative reform, decentralization, elimination of red tape and corruption. But governance has other ramifications that must be considered. Unless a state does a whole array of things to position itself appropriately, it cannot hope to have good governance $^{1}$.

Reform of bureaucracy: Good governance as administrative reform in the third world states is taken to mean reform of bureaucracy. But the real problem is the role of the state in administration and the economy. Most third world states are still lingering in the Weberian dichotomy of state and society, but in advanced societies, the state has been made to retreat in two ways $^{2}$. There has been devolution of power from the centre to the provinces and from there to local government. It is assumed - and experience in the third world proves it right - that a state with centralized authority gives rise to bad governance. In recent times, the state has also retreated from the economy and abandoned the concept of the welfare state. The idea of the

\footnotetext{
${ }^{*}$ Friday Times

${ }^{1}$ Mark Duffield, Global Governance and the New Wars: The Merging of Development and Security, Zed Books, 2000. The real thrust behind the multilateral thrust for good governance has been explained in the book. According to the author, after the collapse of the Soviet Union in 1991, another concept dear to the nation-state, that of state sovereignty, came to an end. Globalization was the new order and a curbing of national sovereignty was built into it. And it manifested itself in the opening of the national market through denationalization, deregulation and free market. State security became an internal matter and the state was told to focus more on internal security rather than on threats perceived from external sources.

${ }^{2}$ Max Weber (1864-1920) was the most forceful opponent of bureaucracy as the instrument of state and placed society in opposition to it. In his various writings he propounded the theory of the weakening of the state through charismatic political leaders representing society against the power of the state. This however did not come to pass.
} 
welfare state was predicated on centralized authority. India did not accept the Cabinet Mission plan of devolution to a confederal structure because Nehru had a socialist welfare state in mind $^{3}$. However after 1947, Pakistan faced problems of national integration and equally opted for a centralized state. In the mid- $20^{\text {th }}$ century centralization was not yet diagnosed as an element of bad governance. Bureaucracy becomes more visibly powerfu1 when a state is centralized than when it is not. On the other hand, if the writ of the state doesn't run across the board, like Afghanistan, to which Pakistan can be compared in parts of its territory, deregulation or decentralization would have a negative effect on governance.

Condition of democracy: The state is known to be efficient if it is democratic, that is, if people are governed with their consent, and that there exists a social contract between state and society. Although an alternative model exists of high growth rate in Asia based on 'guided' capitalism without democracy it is dependent on factors not available in all parts of the world, especially with regard to transition of political power ${ }^{4}$. A more fundamental question relates to the nature of the state. In the nationstate model, in decline in the West and to some extent all over the world, the process of nation-building takes it in a conflictual direction, opening up prospects of periodic or epochal war. (Pakistan and India have engaged in a fifty-year epochal war.) This undermines governance. A state has to be at peace to allow good governance. A study of three nationalisms in South Asia (Pakistan, India, Bangladesh) will reveal that there is overt and subtle conflict in their textbook development. There is the 'painful birth

${ }^{3}$ Sugata Bose \&, Ayesha Jalal, Modern South Asia: History, Culture, Political Economy, Second Edition, OUP, 1994: 'Jinnah of all people should have understood why the hard men in the Congress, especially Sardar Vallabhbhai Patel and Jawaharlal Nehru, needed a strong unitary centre for India, and realised the high price they would pay to achieve it' (P.I 59). The price was of course Pakistan rather than the Cabinet Mission plan.

${ }^{4}$ Michael D. Ban, Lee Kuan Yew:the Belief behind the A fan, Curzon Press, 2001. The West admires Lee Kuan Yew for applying capitalism successfully in a region crawling with communism. He attends Harvard lectures every year and is interviewed on Washington's C-Span TV channel regularly by fawning interviewers. In Asia, he is admired for his advocacy of Asian culture in opposition to liberal democracy sought to be imposed by the West as a precondition. Lee is also a favourite of China. He has steadily built up his relations with Beijing on the basis of the finance that he funnels into that great neighbour. It is in this context that General Musharraf met him after coming to power and was surprised by the pragmatic depth of Lee's rather harsh observations about Pakistan's unrealistic policies. But one must keep in mind that Lee presided over a citystate where his non-democratic regimentation in the social sector worked. Also, the 'Asian model' of growth without democracy is more relevant to 'trading' Southeast Asia than in 'warrior' South Asia. 
syndrome ${ }^{5}$ in Pakistani nationalism, subtexting India's crime of ethnic cleansing in 1947. Bangladesh has a similar subtext against Pakistan that killed 'three million' Bangladeshis in 1971. Indian nationalism as a status quo power is 'defensive' but is equally conflictual by positing India's survival by 'defeating the designs' of its neighbours. In this equation, the smaller anti-status quo state suffers in governance because of its need to remain in a permanent state of emergency. The critical element of disequilibrium rests in the onus of changing the status quo5.

Status quo versus anti-status quo: In the nation-state model there are variations. If the state allows a grand narrative based on the status quo, prospects of good governance are somewhat assured - somewhat because other states in the neighbourhood may be nurtured on a grand narrative of revision and that may force the status quo state into conflict and military preparedness. The anti-status quo state will have a hard time achieving good governance because its nationalism would be directed away from the economic function. It will live mostly under emergency and impose the financial burden of war and military preparedness on society. There is a better prospect of governance in the status quo power than in the antistatus quo power. Military preparedness is a kind of permanent subsidy that saps the economic potential of the state. The condition of being anti-status quo but unequal in power leads to a virulent brand of nationalism, constantly challenging the politician to set governance aside in favour of the 'bigger sacrifice' of changing the status quo. In Pakistan, the paramountcy of the army is owed to this nationalism. If Pakistan wants to go back to normal governance it must amend its nationalism. If the opponents of military rule continue to support the same nationalism they will not succeed in restoring good governance ${ }^{6}$.

\footnotetext{
${ }^{5}$ Ashley J. Tellis, India's Emerging Nuclear Posture, OVP, 2002. The author tells us that India has rationalised its anti-status quo stance vis-a-vis China by unofficially accepting that the territory it lost in Aksai Chin in the Jammu and Kashmir sector was of more strategic value to China (because of the route connecting it with Tibet) than to India. It 'compensated' itself with the thought that the 90,000 km territory claimed by China in Arunachal Pradesh in north-eastern India was still under India's effective control and was of more strategic value to India. This 'adjustment' has allowed India to normalise trade relations with China and minimise its contradictions with its militarily much superior neighbour in the north. It would have been interesting to see if the onus of changing the status quo with China would have complicated the already bad governance in India, as it has done in Pakistan.

${ }^{6}$ The Friday Times, 13 September 2002, Nationalism in Pakistan'. How has China tackled the problem of its anti-status quo nationalism in regard to Taiwan? 'The achievement of China is not in elimination of corruption. Unfortunately, there is more corruption in China today than ever before. The achievement of China is avoidance of
} 
The socialist model: A state may survive if it is representative; also, if it does not exclude any community and allows the provision of human rights without discrimination. A high-growth state may eventually undermine its own creative energy by restricting human rights. State coercion may allow rapid economic growth for some time but may be ultimately negative because of lack of a social contract. A socialist economy is based on ownership of assets by the state but a socialist model usually works better under coercive governance. The capitalist model, though exploitative under an inefficient state, can give scope to creative entrepreneurship. Socialist bureaucracy is cumbersome and opposed to private enterprise. Bureaucracy focuses on the 'welfare' aspects of the economy and not its viability. Above all, bureaucracy does not achieve the kind of rate of growth required by the economy for its survival. The collapse of the Soviet Union and the 'Soviet model' in the Soviet bloc has unfortunately removed the only challenge to unsteady capitalism and its 'deregulation'. After Russia under Gorbachev wound up the Union, leaders governing the Central Asian Slates were revealed as dictators ${ }^{7}$. Socialism with democracy in Nehruvian India was characterised by bad economic governance. It was called 'permit raj' with a 'Hindu rate of growth' and was accompanied by ills of governance associated with poverty. Today socialism is catalogued under bad governance but this may be a simplistic judgement. 'Socialist' measures in the Western democracies seem to work but tend to exacerbate problems of governance in the third world.

State and utopia: A socialist economy can be ideological because of its basis in utopia. Ideology does not allow dissent and is opposed to freedom of expression. Because there can be no opposition in a society devoted to the construction of a Utopia, pure ideological states do not allow political parties end an opposition in the legislature. Ideological states are also totalitarian and run economies planned at the centre. States attracted to this model nationalize the private sector in the interest of egalitarianism and

war at all costs and the use of the economy as an instrument of persuasion at the global level. It is against the status quo in the region (it wants Taiwan back) but it has not acted like Pakistan, jumping headlong into overt and covert war and against a rival it cannot defeat. Instead it has got Taiwan involved in the development of Fujian, the province facing Taiwan across the strait, and whose people speak the same language and belong racially to the same stock as the Taiwanese Chinese. To date, the Taiwanese have directly invested 20 billion dollars in Fujian alone, can buy property there and can take part in local elections.

${ }^{7}$ Shirin Akiner, Sander Tideman \& Jon Hay, Sustainable Development in Central Asia, Curzon Press (1995). The book gives interesting profiles of the post-Scviet Central Asia ruled by leaders who wanted to use their ample natural resources on the basis of their knowledge of 'socialist economies' while their populations clamoured for representation. 
better control of the exploitative aspects of capialism. While infrastructure is developed at a rapid pace in this welfare model, lack of representation and freedom of expression intensifies obsolescence; and economic cycles are mishandled by the state's large orthodox bureaucracies. Ideology usually makes a teleological journey towards Utopia or the promise of a permanent lack of contradictions. In its intermediate phase an ideological state is intolerant of a variant point of view and brooks no dissent. Utopia is of ancient origin but in the $19^{\text {th }}$ century it was thought out in concrete terms by the anarchists and absorbed from them by Marx. This Utopia was leftwing, worker-based, with a lot of 'natural nurture' borrowed from Rousseau and even $\mathrm{Kant}^{8}$. Pakistan has the longing for an ideological teleology and to that extent it is intolerant of dissent.

The Soviet-Chinese models: The Soviet and Chinese models of the ideological state were based on a scientific dialectic. Both reacted to circumstances from within the ruling elite. The Chinese reacted by changing the economic paradigm; the Soviet elite reacted by changing the political paradigm of the ideological state. As a result, the Soviet Union was abandoned while the Chinese ruling elite modified the state and took on the more difficult task of constant 'pragmatic' reform. The static central economic dogma of Maoism was abandoned to save the state from collapsing. The transition was taken to be the transition of the socialist model; and anti-capitalist elements in the world stopped referring to themselves as socialists after refusing to accept that the Soviet Union was a genuinely socialist state. Russia and China saw failure of governance from two different angles. The Soviet party saw failure in terms of defective political governance, responding to the West with which it had a civilizational nexus. The Chinese party saw failure in terms of defective economic governance and ignored the West as it pointed to China's political dissenters. Russia has problems with democracy because of bad performance in economic governance. China is supposed to run into economic problems because of its bad performance in the achievement of democracy. Chinese pragmatism in the realm of foreign policy however continues to secure it against crises of governance.

\footnotetext{
${ }^{8}$ Noam Chomsky, For Reasons of State, The New Press New York (1973 reprinted 2003). Writing as an anarchist, Noam Chomsky in his essay in the book, begins by saying that anarchism is dismissed today because of its inability to yield a political theory and because it remains formless, primitive and Utopian, but it can be usefully employed as a yardstick to understand institutions that are harmful today after serving out their usefulness during a phase of paramountcy of the economy. Anarchism comes in handy after you have realized that the political orders in force have created a material and social deficit. He notes that Engels disagreed with Bakunin that Utopia should begin immediately after Revolution. Chomsky notes that Bakunin was probably right on this point.
} 
Setting aside Third World problems of governance: If governance is to be studied in respect of Pakistan, it would be useful to discuss problems that are specific to Pakistan. This statement is based on the increasing realization that Pakistan's problems of governance are more severe than those of the rest of the third world. For instance, law and order in Pakistan is in a worse condition than in India, that there is more rejection of the political system and more lack of national consensus in Pakistan than in India. This takes us to the case of an accelerated dispersal of governance and the state in Pakistan than in the rest of the world. As for the fundamental problems of poverty in the third world and the complication of governance there owing to poverty, some writers have assumed that poverty should be accepted as a sustainable phenomenon because its removal would mean an ecological collapse of the third world states through high consumption, unless of course birth rates are drastically curbed and brought to zero?

Pakistan should be placed in the third world grid first and its governance should be 'pooled' with the rest of the third world, but if some of the more urgent problems of governance are to be tackled, then problems specific to Pakistan and not common to the third world must be discussed.

Islamic ideological state: Just around the time that socialism collapsed there emerged on the scene the ideological state of Iran. Its intellectual mission statement relied on the tenets of Islam, which were quite similar to those of the Soviet state, but with the difference that the Soviet dogma was based on a dialectic while in the Iranian case the central dogma was based on irreversible revelation. In its early phase, Iran was totalitarian and opposed to dissent like the Soviet Union. There was also the accompanying rapid development of some infrastructure. Rapid progress was made in mass education and some troubled aspects of Islam, like its opposition to contraception, were taken care of because of authoritarianism. But popular

${ }^{9}$ Oswaldo De Rivero, The Myth of Development: the Non-Viable Economies of the $21^{\text {st }}$ Century, Zed Books, 2003: 'How can the quasi-nation states be made economically viable when their populations are growing explosively and their export goods consist of primary goods or only slightly processed products, which fetch low prices and are in little demand? How are we to deal with ungovernable countries where corruption is rife and the daily practice of democracy is rudimentary at best? How are market economy and consumer society to be produced in Latin America. Asian and African countries that have more than 40 percent of their population living below the poverty line, on less than one dollar a day? How are nearly 5 billion persons with low incomes to be integrated into global consumption patterns, without seriously damaging the biosphere? How is the enormous gap between the rich and poor countries to be closed without gravely affecting the planet's ecological balance?' 
disaffection grew with the governance of a non-consensual state that allowed little freedom of expression and performed badly economically despite its oil-producing status. And the disaffection grew more quickly than in the quondam Soviet Union. An Islamic ideological state has certain continued contours based on jurisprudential 'consensus'. The elimination of political parties and opposition from parliament/Majlis/shura was also envisaged by Pakistan in the Ansari Commission Report in the light of which the General held his 1985 'partyless' elections which returned a parliament without opposition $^{10}$. By deviating from the Iranian norm, Pakistan became an 'incompletely' ideological state, a state without consensus. As the Iranian and later the Afghan model proved, an Islamic ideological state remains unstable until the shariah is enforced by the clergy. Stability is achieved through ideologically mandated coercion. As long as the clergy remains out of power, an environment of rejectionism surrounds all efforts at attaining ideological purity. In this perspective Pakistan remains a Caliban-like incomplete entity.

The 'incomplete' Islamic ideological state: An 'incompletely ideological' state like Pakistan has all the ills of an ideological state without its benefits. Its governance is not only bad, it is more difficult to achieve. Its 'incompleteness' keeps the nation in a constant mood of disaffection. Institutions like the Council for Islamic Ideology, by constantly making demands for further 'reforms' in favour of the revealed tenets, spread the feeling that the ruling elite is not interested in enforcing the true dogma (shariah). A democratic system, an opposition in parliament and a proliferation of political parties, are all clearly a violation of the shariah. The shariat on the Statute books does not please the masses because it is never enforced. The cutting of hands, the stoning to death, the abolition of bank interest, have never been carried out in reality, thus convincing the nation that the state is cursed because of its insincerity. In the case of Pakistan, the ancient post-Madina rejectionism of all institutions adds to the difficulties of governance. The Federal Shariat Court remains non-consensual among the clergy because it is inclusive rather than exclusive. The principle of inclusion

${ }^{10}$ Shariful Mujahid; Ideology of Pakistan, Islamic Research Institute, International Islamic University Islamabad 2003: Maulana Zafar Ahmad Ansari (1908- W I) wrote on the Islamic concept of sovereignty in his celebrated articles in Dawn in 1955 answering the objections of many who thought that sovereignty could only belong to the people and not to Allah as premised in Islam. Before Ansari became an important factor in the debate on ideology he was assistant secretary of the All-India Muslim League in Daryaganj, Delhi, feeding important scholarly advice to the Muslim leader, Liaquat Ali Khan (1895-1951) in his capacity of secretary, Committee of Action, and secretary, Central Parliamentary Board. That made Ansari an important repository of the thinking of the Muslim leaders campaigning for the establishment of Pakistan. 
is enshrined in the wording of the Constitution which says any law 'not repugnant to Islam' would be accepted as valid. A glaring example of complication in governance was the revolt of Sufi Muhammad in Malakand who set up his qazi courts. The province submitted to him by allowing qazi courts of its own, proving once again that Islamic rejectionism was a genuine problem. An incomplete ideological state is also under constant invasion from 'hard' Islam from abroad, particularly the Arab brand, backed by generous dollar funding. Individual judges in the higher judiciary may be persuaded by a more conservative Islam than is allowed by the jurisprudence of Hanafi law in Pakistan. Serving judges have openly revolted against caselaw, firm in their belief that their hard version was valid. This has led to contradictory judgements and complications of governance.

'Amr' and 'nahi' or Islamic vigilantism: An Islamic state proves difficult to reform, unlike the Soviet and Chinese states. It is also impossible to govern unless it is run by the clergy as a theocratic state. The main reason is the basic concept of amr and nabi embedded in the shariah. Will the state stop that which is not good or will the individual do it? Although great medieval thinkers like Imam Ghazali have written about it, there is no consensus among the Muslims over the application of the doctrine ${ }^{11}$. The problem is resolved if the state goes theocratic because then the ruling clergy is allowed to suppress fellow-clerics in order to appropriate the right of enforcing amr and nabi. Th doctrine lies at the root of governance and internal sovereignty of the state. The doctrine is especially relevant in the case of jihad. Let us consider the governance-related aspects of amr and nabi. The problem is that amr and nabi could have become obsolete in our day because of the setting up of a modern state, the framing of a constitution, the preparation of the penal code, and the establishment of a police department. If you think that something wrong is being done or that something right is not being done, you can look up the penal code, and if the act is described as a crime, you can go to the police station and register an FIR. In other words, the state is the enforcer of amr and nabi. If someone ignores this and enforces amr and nabi on his own, he would seem as taking the law $m$ his own hands and would be committing a crime himself. Nabi when enforced like this can be dangerous. In Pakistan, often when an individual tries to stop eve-teasing or rebukes persons not observing the fast, he is attacked by the violators and sometimes even killed. Despite evidence that only the state should enforce the concept of nabi, the clergy in Pakistan continues to resort to vigilant action, as was witnessed in Gujranwala in Punjab on 3 April 2005

${ }^{11}$ Michael Cook; Commanding Right and Forbidding Wrong in Islamic Thought, Cambridge University Press (2000). 
when a marathon was attacked by a local MNA belonging to the Mutahidda Majlis-e-Amal (MMA) ${ }^{12}$.

Governance under jihad: Jihad has been enjoined in the Quran and therefore lies at the base of the shariah. It is not however clear in Pakistan whether the state should wage jihad or it is incumbent on each individual to do so. This is very important because it relates to the doctrine of low-intensity and deniable warfare that the state of Pakistan has been practising in the recent past. It violates international law that enjoins the state to declare war and does not recognize individuals in this respect. In terms of governance, the state has to surrender internal sovereignty because private jihadi organisations have to be located in civil society and have to be exempted from municipal law in respect of their use of weapons and training. States can tolerate diminution of external sovereignty -mostly owing to economic weakness -- but they cannot survive surrender of internal sovereignty. There can be no governance when the state is not sovereign even internally. The problem of 'extraterritoriality' is the most pressing problem in Pakistan's governance. More than 50 percent of the territory is already outside the municipal jurisdiction of the state since Pakistan has failed to bring the whole of Balochistan under the normal writ of the state and has preserved the Federally Administered Tribal Areas (FATA) as a relic of the British Raj 'buffer' territory. Jihad has extended 'extraterritoriality' or 'no-go areas' to the big cities of Pakistan. In the smaller cities the entire administration may be run by non-state actors, as happened in Toba Tek Singh when Lashkar-e-Tayba was the most powerful ISI-supported militia in Pakistan. (Lashkar-e-Tayba also ran a court in Lahore and advertised it in the newspapers.) Any discussion of law and order in Pakistan in the past has run headlong into the state's policy of Jihad. Because jihad was fought with mercenary troops there was a sharing of the sovereignty of the state with jihadi leaders, reminiscent of the Italian city-states in the Middle Ages ${ }^{13}$. There is resistance among politicians to the post-9/11 perceived policy of giving up

\footnotetext{
${ }^{12}$ Writing in Jang (6 April 2005) "Nazeer Naji stated that the MMA leader MNA Qazi Hameedullah who attacked the marathon in Gujranwala along with his extremist seminarians on April 3 was a hardline Pushtun cleric with a Taliban background. Daily Pakistan wrote that Qazi Hameedullah led a batch of Afghan students who were illegally staying at his seminary. The police said that a raid would soon be conducted into the seminaries to apprehend illegal Taliban students.

${ }^{13}$ Machiavelli (d.1532) in The Prince: 'Mercenaries and auxiliaries are useless and dangerous. For mercenaries are disunited, thirsty for power, undisciplined and disloyal; they are brave among their friends and cowards before the enemy. In peacetime you are despoiled by them and in wartime by the enemy. Mercenary commanders [cannot be trusted] because they are anxious to advance their own greatness, either by coercing you, or by coercing others against your wishes. Experience has shown that only armed princes and republics achieve solid success, and that mercenaries bring nothing but loss.'
} 
jihad because the world increasingly equates it to terrorism. There is apparently no realisation that jihad militates against governance above a11 ${ }^{14}$.

Governance and 'exclusion': An Islamic ideological state excludes nonMuslims and women in general and apostatizes certain communities. When this happens, certain individuals and communities are excluded from the ambit of rights and certain others become qualified as potential 'excludables'. The Islamic state has to be in a permanent process of selfpurification. If a law doesn't work, it cannot be changed because of the literalist divine sanction behind it. After apostatized communities are excluded more sectarian communities seem to become qualified for apostatization. That leads to conflict and the creation of an environment of insecurity in which no governance can succeed. In fact governance is further exacerbated by the creation of private security systems within the state in the form of sectarian militias. State functionaries adhere to the ideology of purification for which sanction is sought by them from the tradition of Islamic rejectionism in general and the Pakistan -specific problem of a consciousness of being 'incompletely' Islamic. Such functionaries have actually taken part in sectarian killings or sided with co-sectarians during sectarian conflict ${ }^{15}$. State functionaries are similarly inclined to look at the Ismailis suspiciously. This attitude springs from the understanding that the state is religious and must move towards purification. If and when a theocracy is established in Pakistan the state functionaries will move against the Ismailis the same way they have moved, under law, against the Ahmedis. They have tacitly allowed outrages against the Shia too and caused a deep rift of suspicion against the state. This trend is in line with the way the

\footnotetext{
${ }^{14}$ As reported in Nawa-e-Waqt (25 May 2002), Nawabzada Nasrullah Khan, chairman of an opposition alliance, said that General Musharraf's pledge to the world and India about not allowing Pakistan's soil to be used for terrorism was not acceptable. He said that these decisions went against the popular will and would be undone. Daily Jang reported that Nawaz Sharif stated from Saudi Arabia that General Musharraf had sold the country down the river 'by submitting to India'.

${ }^{15}$ Monthly Newsline (June 2001) actually wrote that the intelligence agencies were 'in' with the sectarian terrorists: 'The official quoted above has no hesitation in accusing the 1ST of orchestrating such (Shia) murders through the militants of sectarian parties, adding that Sipah Sahaba terrorists are trained by the agency. The Sipah Sahaba are supported by the MQM Haqiqi Group. Sources reveal that Sipah Sahaba's (sic?) Riaz Basra has been spotted in the company of a colonel who has also given him shelter in his house. Similarly, when three members of Lashkar-e-Jhangvi were picked up by the police, another colonel, who identified himself as their PRO, requested that they be released forthwith'. Basra's own militia Lashkar-e-Jhangvi was a breakaway splinter of Sipah. It should be noted that after his death Basra was buried wrapped in the flag of Sipah-e-Sahaba. Karachi killed 450 people in cases of sectarian violence since General Musharraf took over the government in October 1999.
} 
'completely' ideological states of Iran and Afghanistan (under Taliban) have acted in the past.

Governance without secularism: Pakistan as an incomplete ideological state has carried out the exclusion of the Ahmedis but is balking at the formal exclusion of the Shia community. After the possible exclusion of the Shia, at least two more communities will become qualified as 'excludable'. The completely ideological state of Iran has excluded the Sunni community and Iraq, in the long run, may move under democracy to exclude the Sunnis after a long period of exclusion of the Shia under Saddam Hussein. The Islamic state faces failure of governance in this age of global economic interconnection. There is no sign that the tenets of the Islamic ideological state might be altered, above all, the doctrine of mixing religion with politics. Governance today is associated with decentralization of authority and in freeing the economic sector from state diktat. Mixing religion with governance negates that. At root is the problem of the 'deductive' discourse of religion also called kalam: accept the premise as unchallengeable and unamendable, then project logically the consequences that it must register. The nature of knowledge under religion must remain fixed on causes rather than consequences, leading the state to presume that the only way forward is by forcibly changing the conditions of life in accordance with the ideological premise. This robs the state of flexibility of response to crises as they occur. The state becomes ungovernable when its population refuses, by training, to accept the rational choice and insists on inviolable 'principles'. An Islamic state may enjoy relatively good economic and social indicators but may have the highest ratio of 'intellectual' unhappiness among its people at the same time. There is little realization that a lack of flexibility of response means a lack of ability to self-correct, a quality associated with the United States which the people of Pakistan see as the foe of the transnational umma.

Governing a pessimist population: Muslims have a sense of the world Muslim community like no other religious population. Among the Muslims of the world, the South Asian Muslims have always felt 'outward' rather than 'inward'. A pan-Islamic sense has always pervaded their worldview, and Pakistan, after emerging as a nation-state, had to acknowledge it as a part of its ideology. The 'transnational' feeling is integral to the idea of the grand Muslim diaspora after the seventh century. It emerged from the pattern of the spread of Islam through hijrah (migration) and conversion. During the days of subjugation to foreign empires, the transnational feeling contributed to the organization of resistance among local Muslim populations. In India, Muslim existence was deemed a kind of permanent emergency (dar-ul-harb) and migration was considered an option in the defiance of British Raj. 
Today, the Muslims of Pakistan find it difficult to accept the international view that Pakistan has improved its internal order and its economy, as they focus on the 'misfortunes' of the Muslim communities abroad. There is a strong tendency among Pakistanis to reject the good tidings and interpret positive developments as 'conspiracy' to lull the umma into quiescence. On the other hand, India is increasingly identified as being peopled with optimists. Indian writers describe the post-1990 era as a period of the positive outlook. External writers marvel at the size of the problems India faces as a society and show surprise at the nation's willingness to tackle them with a positive mind ${ }^{16}$.

${ }^{16}$ The Economist, April 9 ${ }^{\text {th }}$, 2005: Reviewing Suketu MeJita's book Maximum City: Bombay Lost and Found, the writer stated: 'Mr. Mehta paints a picture of an India that is so vast, complex and confusing as to defy generalisation, and facing such terrifying array of problems that it forbids optimism. Yet most of his characters show the intrinsic propensity for not losing hope'. 